\title{
The function of stilt roots in the growth strategy of Socratea exorrhiza (Arecaceae) at two neotropical sites
}

\author{
Gregory R. Goldsmith ${ }^{1,2}$ \& Rakan A. Zahawi ${ }^{3}$ \\ 1 Department of Biology, Bowdoin College, 6500 College Station, Brunswick, Maine 04011, USA; \\ grgoldsmith@gmail.com \\ 2 Department of Integrative Biology, 3060 Valley Life Sciences, University of California Berkeley, Berkeley, California \\ 94720, USA. \\ 3 Organización para Estudios Tropicales, Apartado 676-2050, San Pedro, Costa Rica.
}

\author{
Received 27-I-2006. Corrected 05-XII-2006. Accepted 08-V-2007.
}

\begin{abstract}
Arboreal palms have developed a variety of structural root modifications and systems to adapt to the harsh abiotic conditions of tropical rain forests. Stilt roots have been proposed to serve a number of functions including the facilitation of rapid vertical growth to the canopy and enhanced mechanical stability. To examine whether stilt roots provide these functions, we compared stilt root characteristics of the neotropical palm tree Socratea exorrhiza on sloped $\left(>20^{\circ}\right)$ and flat locations at two lowland neotropical sites. S. exorrhiza $(\mathrm{n}=80$ trees) did not demonstrate differences in number of roots, vertical stilt root height, root cone circumference, root cone volume, or location of roots as related to slope. However, we found positive relationships between allocation to vertical growth and stilt root architecture including root cone circumference, number of roots, and root cone volume. Accordingly, stilt roots may allow S. exorrhiza to increase height and maintain mechanical stability without having to concurrently invest in increased stem diameter and underground root structure. This strategy likely increases the species ability to rapidly exploit light gaps as compared to non-stilt root palms and may also enhance survival as mature trees approach the theoretical limits of their mechanical stability. Rev. Biol. Trop. 55 (3-4): 787-793. Epub 2007 December, 28.
\end{abstract}

Key words: Barro Colorado Island, La Selva Biological Station, light gaps, palm architecture, Socratea exorrhiza, stilt roots.

Tropical wet rain forest trees use several root architectural strategies to cope with a number of harsh edaphic conditions including waterlogging, poorly developed soil profiles, and unstable soils (Dransfield 1978). Jeník (1978) identifies at least 25 model root systems in tropical trees, of which the most striking are buttresses and stilt or aerial adventitious roots. Stilt roots have evolved in many plant families, but most species belong to the Arecaceae (Richards 1996). Iriarteoid palms, which include the genus Socratea H. Karst., have stilt roots that arise from the lower portion of the stem and grow freely in the air until they make contact with the ground and root (Kahn and de Granville 1992). In Socratea exorrhiza (Mart.)
H. Wendl., a common lowland neotropical species, stilt roots begin establishing almost immediately following seedling germination (Kahn and de Granville 1992). Mature S. exorrhiza demonstrate great individual variation in stilt root patterns with respect to the number, size, and height of roots, such that their function has been debated extensively.

Despite a number of proposed hypotheses, the function of stilt roots in palms remains poorly understood. In a now refuted hypothesis (Dransfield 1978, Kahn and de Granville 1992), Corner (1966) suggested that stilt root palms were associated with areas prone to water-logging and flooding. Bodley and Benson (1980) coined the term "walking palm" by observing 
saplings of S. exorrhiza 'escape' from beneath fallen debris by developing new roots on the opposing side of a disturbance and effectively righting themselves by allowing old roots to rot away. In turn, Swaine (1983) observed that stilt roots may allow individuals to establish at ephemeral sites or sites with high amounts of debris by shifting the rooting location so as to avoid organic debris such as logs. Some studies have also suggested that stilt roots may act as tensioning buttresses and improve anchoring in less-developed substrates or in areas of high wind stress (Henwood 1973, Jeník 1978, Richter 1984). The association of Iriarteoid palms with steep sloped habitats has led to the suggestion that stilt roots may be an adaptation to unstable conditions and provide mechanical stability against uprooting (Henderson 1990, Chiatante et al. 2002). However, Avalos et al. (2005) concluded that stilt roots do not provide enhanced stability on sloped locations, and found that stilt root architecture is instead a function of stem volume.

In addition to hypotheses addressing enhanced structural stability, it has also been suggested that stilt roots allow for a unique vertical growth strategy. Hartshorn (1983) suggested that stilt roots in S. exorrhiza may facilitate rapid growth towards the canopy when light becomes available in the understory. This hypothesis is supported by evidence that stilt root palms have earlier vertical stem development than palms without stilt roots, and do so by reducing allocation to belowground roots and developing progressively higher stilt root height (Schatz et al. 1985). As young palms are mechanically overbuilt with respect to their diameter, the benefit of earlier allocation to vertical growth may confer an advantage on $S$. exorrhiza as compared to non-stilt root palms (Rich 1986, Rich et al. 1986). Despite several hypotheses addressing vertical height in relation to biomass allocation, no research has directly examined whether vertical growth is positively correlated with stilt root structure.

This study first examined the root stability hypothesis of $S$. exorrhiza on sloped and flat locations. We predicted that number of roots, vertical stilt root height, root cone circumference, and overall root cone volume would be greater for individuals on sloped than flat locations. We further predicted that palms on slopes would have a greater number of stilt roots on the upslope side to provide tensioning support. Secondly, the study explored the vertical growth hypothesis with respect to the relationship between stilt root structure and allocation to vertical height within a fixed stem diameter range. We predicted that trees with a larger ratio of stem height to stem diameter would demonstrate a positive relationship with stilt root characteristics as necessary to support greater vertical growth.

\section{MATERIALS AND METHODS}

Study sites: data were collected in October 2004 at La Selva Biological Station, Costa Rica $\left(10^{\circ} 26^{\prime} \mathrm{N}, 83^{\circ} 59^{\prime} \mathrm{W}\right)$ and in November 2004 on Barro Colorado Island (BCI), Panama ( $9^{\circ} 09^{\prime} \mathrm{N}$, $\left.79^{\circ} 51^{\prime} \mathrm{W}\right)$. La Selva is characterized by primary and secondary tropical wet lowland forest with an annual rainfall of approximately 4000 $\mathrm{mm}$ and average annual air temperature of 25.8 ${ }^{\circ} \mathrm{C}$ (McDade and Hartshorn 1994, Sanford et al. 1994). Palms were sampled in primary forest on inceptisols (Sollins et al. 1994). BCI is characterized by primary and secondary tropical moist forest with an annual rainfall of 2600 $\mathrm{mm}$, but with a 4-month dry season, and average annual temperature of $27^{\circ} \mathrm{C}$ (Deitrich et al. 1992). Palms were sampled in primary forest on alfisols (Yavitt and Wieder 1988).

Sampling: twenty palms each were sampled on sloped $\left(\geq 20^{\circ}\right)$ and flat upland locations at both La Selva and BCI ( $\mathrm{n}=80$ trees total). Stem diameter was measured just above the emergence point of the highest stilt root. Palm height was measured just below the crown using a 400XL laser rangefinder and corrected for observer's height (Opti-logic Inc., Tullahoma, $\mathrm{TN})$. Vertical stilt root height was measured from the ground to the point of highest stilt root attachment on the stem, and number of 
roots was counted for each tree. Root cone circumference was measured at ground level and encompassed all attached roots. To determine above-ground root volume, the volume of each root was calculated as for a cylinder by measuring the length and diameter at the midpoint of each root. Only roots connected to the soil were included in data collection; however, it was difficult to assess whether all connected roots were fully functional. For palms on slopes, the number of upslope and downslope roots was quantified relative to the prevailing slope direction.

Multivariate Analysis of Variance (MANOVA) was used to analyze differences between flat and sloped locations at La Selva and BCI for number of roots, vertical stilt root height, root cone circumference, and root cone volume. As detection of a significant treatment effect in a MANOVA does not differentiate within response variables, univariate ANOVAs were used to determine differences for response variables within a treatment. A two-way analysis of variance (ANOVA) was used to analyze differences between the number of upslope and downslope roots at La Selva and BCI.

To examine the relationship between stilt root architecture and stem height, stem diameter was restricted to $12-17.5 \mathrm{~cm}$ for all palms sampled. By utilizing a fixed stem diameter range, a greater ratio of stem height to stem diameter would correspond to increased allocation to vertical growth. With the ratio of stem height to stem diameter calculated for each tree, an analysis of covariance (ANCOVA) was used to compare relationships between this ratio and each measured stilt root characteristic. Each relationship was also compared by location. All statistical assumptions were met and analyses conducted as generalized linear models (GLM) using JMP 5.1.2 (SAS Institute 2004).

\section{RESULTS}

Number of roots, vertical stilt root height, root cone circumference, and root cone volume demonstrated a whole model effect (Wilks' Lambda, $\left.\mathrm{F}_{12,188}=4.97, \mathrm{p}<0.001\right)$. While there was no difference between flat and sloped locations $\left(\mathrm{F}_{4.71}=1.41, \mathrm{p}=0.2408\right)$, there was an effect of site $\left(\mathrm{F}_{4,71}=11.08, \mathrm{p}<0.001\right)$ and an interaction between site and location $\left(\mathrm{F}_{4,71}=14.84\right.$, $\mathrm{p}=0.014)$. Only vertical stilt root height was found to vary between sites (Table 1).

For palms on slopes, there was no significant difference in the number of upslope and downslope roots $\left(\mathrm{F}_{1}=3.034, \mathrm{p}=0.086\right)$. Additionally, there was no effect of site $\left(\mathrm{F}_{1}=1.027, \mathrm{p}=0.314\right)$ and no interaction between site and location $\left(\mathrm{F}_{1}=0.372, \mathrm{p}=0.543\right)$.

Mean stem height of all trees was 14.16 $\mathrm{m}( \pm 0.17$ S.E.), and mean stem diameter was $14.74 \mathrm{~cm}$ ( \pm 0.16 S.E.). The stem height to stem diameter ratio was positively related to root cone volume $\left(\mathrm{r}^{2}=0.390, \mathrm{p}=0.001\right)$, root cone circumference $\left(\mathrm{r}^{2}=0.194, \mathrm{p}=0.001\right)$, and number of stilt roots $\left(\mathrm{r}^{2}=0.320, \mathrm{p}=0.001\right.$; Fig. 1$)$. There was no relationship between the stem height to diameter ratio and stilt root height $\left(r^{2}=0.001\right.$,

TABLE 1

Mean ( \pm 1 SE) values for stilt root characteristics of Socratea exorrhiza at La Selva Biological Station, Costa Rica, and Barro Colorado Island, Panama

$\begin{array}{lccccc} & \text { La Selva } & \text { BCI } & \text { F } & \text { DF } & p \\ \text { Root Cone Volume }\left(\mathrm{m}^{3}\right) & 0.035 \pm 0.004 & 0.043 \pm 0.004 & 1.989 & 1 & 0.162 \\ \text { Root Cone Circumference }(\mathrm{m}) & 4.30 \pm 1.89 & 4.28 \pm 1.94 & 0.004 & 1 & 0.950 \\ \text { Number of Roots } & 16.83 \pm 1.04 & 16.2 \pm 0.95 & 0.399 & 1 & 0.621 \\ \text { Vertical Stilt Root Height (m) } & 1.83 \pm 0.06 & 1.54 \pm 0.04 & 14.84 & 1 & <0.001 \\ & & & & & \end{array}$



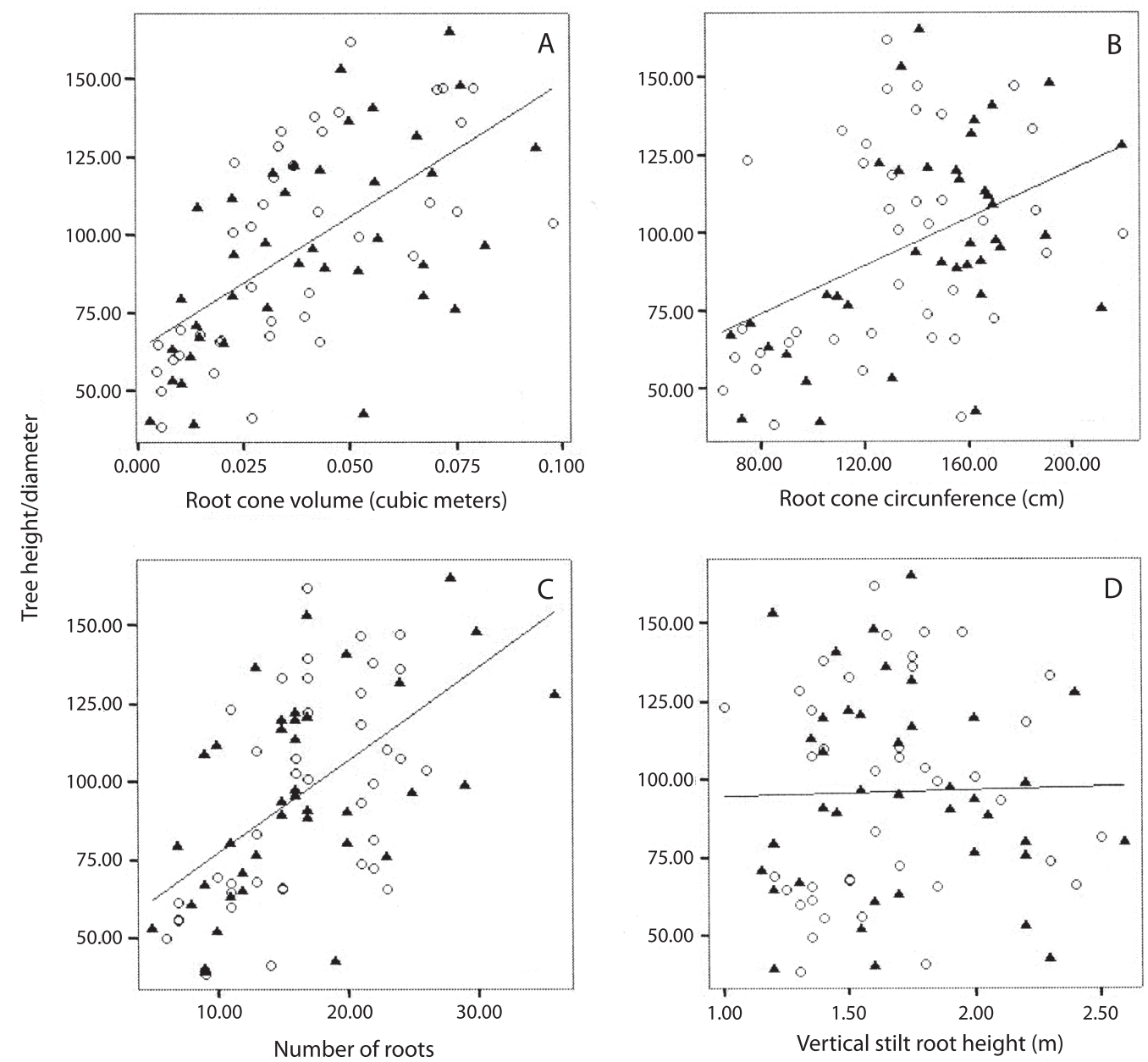

Fig. 1. Relationship of the ratio of stem height to stem diameter with stilt root characteristics in Socratea exorrhiza. Regressions with a) root cone volume $\left(r^{2}=0.390, p<0.001\right)$; b) root cone circunference $\left(r^{2}=0.194, p<0.001\right)$; c) number of roots $\left(r^{2}=0.320, p<0.001\right)$; $)$ vertical stilt root height $\left(r^{2}=0.001, p=0.836\right)$. There was no significant effect of location slope (A) vs. flat $(\bigcirc)$ on any relationship (ANCOVA, $\mathrm{p}>0.05$ ).

$\mathrm{p}=0.836$; Fig. 1). There was no effect of location on these relationships $(\mathrm{p}>0.05)$.

\section{DISCUSSION}

It was predicted that palms would alter their architecture with respect to location by adding stilt roots, altering stilt root location, increasing vertical stilt root height, developing a wider structural base via increased root cone circumference, or adding root volume for enhanced physical stability. However, stilt root architecture did not differ between trees on sloped and flat locations. This supports previous work that $S$. exorrhiza alters neither its physical structure nor its investment in stilt roots in relation to degree of slope (Avalos et al. 2005). The difference in stilt root height between La Selva and BCI may reflect site-specific abiotic conditions or population characteristics; however, it is unlikely that the 
difference $(<0.3 \mathrm{~m})$ on trees averaging over $14 \mathrm{~m}$ height is of biomechanical significance. Furthermore, there was no relationship found between stilt root height and the stem height to diameter ratio. The absence of significant differences by location does not preclude the role of stilt roots in providing stability as suggested by a number of previous studies (Jeník 1978, Henderson 1990, Kahn and de Granville 1992). Likewise, stilt roots likely enhance germination and establishment in disturbed locations, or on sloped sites (Swaine 1983, Schatz et al. 1985, Henderson 1990).

Hartshorn (1983) suggested that stilt roots in S. exorrhiza may confer a competitive advantage by allowing a tree to attain canopy height through rapid vertical growth without investing in increased stem diameter. Palms lack the stiffening properties of a secondary cambium and grow relatively thinner with respect to height at maturity as compared to dicotyledonous trees, such that they approach the theoretical limits of mechanical stability (Rich et al. 1986). Greater structural support can be attained only by increasing stem diameter prior to vertical growth or by the stiffening of tissue via lignification (Rich 1986). However, the immediate development of stilt roots following seedling germination may provide a wider physical structure and allow for growth in height without a concomitant growth in diameter (Schatz et al. 1985, Henderson 1990).

Our results provide evidence supporting the vertical growth strategy hypothesis. A positive relationship was found between the allocation of biomass to vertical growth and stilt root structure. As individuals increase number of roots, cone circumference, and cone volume, stems can grow vertically without a concomitant increase in stem diameter. By utilizing stilt roots, S. exorrhiza and other Iriarteoid palms may reach the canopy at a faster rate and without the same costly allocation of biomass for stem or belowground root growth required by non-stilted palms. At greater heights, stilt roots may also compensate for the mechanical instability of relatively taller and thinner individuals, whereas palms without stilt roots depend solely on underground root structure. Although non-stilted palms such as Welfia georgii $\mathrm{H}$. Wendl. allocate twice the biomass towards underground root structure (Schatz et al. 1985), this root design is likely less stable than the broader cone associated with stilt roots. As such, stilt roots may initially facilitate early growth towards available canopy light and then provide enhanced mechanical stability at maturity.

The rapid vertical growth strategy is consistent with descriptions of $S$. exorrhiza as a light gap colonizing pioneer species (Yeaton 1979, Kahn and de Castro 1985, Rich 1986). Although Hogan (1986) found S. exorrhiza to be shade-adapted as compared to the nonstilt palm Attalea rostrata Oest. (referred to as Scheelea zonensis L.H. Bailey), it is likely that $S$. exorrhiza is simply more shade-tolerant and is also able to exploit available light gaps. The species is capable of growing to maturity under a closed canopy, but grows significantly faster in minor light gaps (Vandermeer et al. 1974), and despite research into a non gap-dependency hypothesis, no conclusive results were determined for S. exorrhiza (Svenning 1999).

An enhanced understanding of the function of stilt roots in the growth and rooting strategies of palms can be utilized in further studies of a gap-dependency hypothesis and other broader community-level studies. This study suggests that stilt roots in S. exorrhiza are a novel strategy to rapidly attain vertical height without compromising mechanical stability. The mechanism may confer an advantage by allowing $S$. exorrhiza to rapidly colonize light gaps and may be one reason why the species is prevalent in lowland neotropical forests.

\section{ACKNOWLEDGMENTS}

We gratefully acknowledge W.L. Whitlow, C.K. Augspurger, G.A. Avalos, and two anonymous reviewers for comments on earlier drafts of the manuscript. Logistical support for this study was provided by the Organization for 
Tropical Studies and the Smithsonian Tropical Research Institute.

\section{RESUMEN}

Comparamos características físicas de raíces aéreas de la palmera Socratea exorrhiza en sitios inclinados (pendiente $>20^{\circ}$ ) y sitios planos, en dos lugares neotropicales. S. exorrhiza ( $\mathrm{n}=80$ árboles) no muestra diferencias en el número de raíces, la altura vertical de las raíces, la circunferencia y la masa del cono de las raíces, o la posición de las raíces en los sitios con pendiente. Encontramos relaciones positivas entre el crecimiento vertical y la arquitectura de las raíces aéreas, incluso entre el número de raíces, la circunferencia del cono de las raíces, y la masa del cono de las raíces. Es posible que las raíces aéreas permitan a $S$. exorrhiza crecer en altura y mantener la estabilidad mecánica sin involucrar el diámetro del tallo y la estructura de las raíces subterráneas. Probablemente, esta estrategia incrementa la capacidad de la especie para usar claros de luz rápidamente, en comparación con palmeras carentes de raíces aéreas; posiblemente también exista un incremento en su supervivencia cuando las adultas palmeras se acercan a sus límites de estabilidad mecánica.

Palabras clave: arquitectura de palmeras, claros de luz, Estación Biológica La Selva, Isla de Barro Colorado, raíces aéreas, Socratea exorrhiza.

\section{REFERENCES}

Avalos, G., D. Salazar \& A.L. Araya. 2005. Stilt root structure in the neotropical palms Iriartea deltoidea and Socratea exorrhiza. Biotropica 37: 44-53.

Bodley, J.H. \& F.C. Benson. 1980. Stilt-root walking in an Iriarteoid palm in the Peruvian Amazon. Biotropica 12: $67-71$.

Chiatante, D., S.G. Scippa, A. Di Iorio \& M. Sarnataro. 2002. The influence of steep slopes on root system development. J. Plant Growth Regul. 21: 247-260.

Corner, E.J.H. 1966. The natural history of palms. University of California, Berkley, California, USA.

Dietrich, W.E., D.M. Windsor \& T. Dunne. 1992. Geology, climate and hydrology of Barro Colorado Island, p. 21-46. In E.G. Leigh Jr., A.S. Rand \& D.M. Windsor (eds.). The Ecology of a Tropical Forest: Seasonal Rhythms and long-term Changes. Smithsonian Institute, Washington D.C, USA.
Dransfield, J. 1978. Growth forms of rainforest palms, p. 247-268. In P.B. Tomlinson \& M.H. Zimmerman (eds.). Tropical Trees as Living Systems. Cambridge University, Cambridge, England.

Hartshorn, G.S. 1983. Introduction: plants, p. 146. In D.H. Janzen (ed.). Costa Rican natural history. University of Chicago, Chicago, Illinois, USA.

Henderson, A. 1990. Arecaceae. Part I. Introduction and the Iriarteinae. Flora Neotropica Mon. 53: 1-100.

Henwood, K. 1973. A structural model of forces in buttressed neotropical rain forest trees. Biotropica 5: 83-93.

Hogan, K.P. 1986. Plant architecture and population ecology in the palms Socratea durissima and Scheela zonensis on Barro Colorado Island, Panama. Principes 30: 105-107.

Jeník, J. 1978. Roots and root systems in tropical trees: morphological and ecological aspects, p. 323-349. In P.B. Tomlinson \& M.H. Zimmerman (eds.). Tropical trees as living systems. Cambridge University, Cambridge, England.

Kahn, F. \& A. de Castro. 1985. The palm community in a forest community of Central Amazonia, Brazil. Biotropica 17: 210-216.

Kahn, F. \& J.J. de Granville. 1992. Palms in forest ecosystems of Amazonia. In W.D. Billings, F. Golley, O.L. Lange, J.S. Olson \& H. Remmert (eds.). Ecological Studies, Vol. 95. Springer-Verlag, Berlin, Germany.

McDade, L.A. \& G.S. Hartshorn. 1994. La Selva Biological Station, p. 6-14. In L.A. McDade, K.S. Bawa, H.A. Hespenheide \& G.S. Hartshorn (eds.). La Selva: ecology and natural history of a neotropical rain forest. University of Chicago, Chicago, Illinois, USA.

Rich, P.M. 1986. Mechanical architecture of arborescent rain forest palms. Principes 30: 117-131.

Rich, P.M., K. Helernum, D. Kearns, S.R. Morse, M.W. Palmer \& L. Short. 1986. Height and stem diameter relationships for dicotyledonous trees and arborescent palms of Costa Rican tropical wet forest. Bull. Torrey Bot. Club 113: 241-256.

Richards, P.W. 1996. The tropical rain forest. Cambridge University, London, England.

Richter, W. 1984. A structural approach to the function of buttresses in Quararibea asteropelis. Ecology 65: 1429-1435. 
SAS Institute. 2004. JMP 5.1.2. SAS Institute, Cary, North Carolina, USA.

Sanford Jr., R.L., P. Paaby, J.C. Luvall \& E. Phillips. 1994. Climate, Geomorphology, and Aquatic systems, p. 34-53. In L.A. McDade, K.S. Bawa, H.A. Hespenheide \& G.S. Hartshorn (eds.). La Selva: ecology and natural history of a neotropical rain forest. University of Chicago, Chicago, Illinois, USA.

Schatz, G.E., G.B. Williamson, C.M. Cogswell \& A.C. Stam. 1985. Stilt roots and growth of arboreal palms. Biotropica 17: 206-209.

Sollins, P., F. Sancho M., R. Mata Chi \& R.L. Sanford Jr. 1994. Soils and soil process research, p. 34-53. In L.A. McDade, K.S. Bawa, H.A. Hespenheide \& G.S. Hartshorn (eds.), La Selva: ecology and natural history of a neotropical rain forest. University of Chicago, Chicago, Illinois, USA.
Svenning, J.C. 1999. Recruitment of tall arborescent palms in the Yasuní National Park, Amazonian Ecuador: are large treefall gaps important? J. Trop. Ecol. 15: 355-366.

Swaine, M.D. 1983. Stilt roots and ephemeral germination sites. Biotropica 15: 240.

Vandermeer, J.H., J. Stout \& G. Miller. 1974. Growth rates of Welfia georgii, Socratea durissima, and Iriartea gigantea under various conditions in a natural rainforest in Costa Rica. Principes 18: 148-154.

Yavitt, J.B. \& R.K. Wieder. 1988. Nitrogen, phosphorous and sulfur properties of some forest soils on Barro Colorado Island, Panama. Biotropica 20: 2-10.

Yeaton, R.I. 1979. Intraspecific competition in population of the stilt palm Socratea durissima (Oerst.) Wendl. on Barro Colorado Island, Panama. Biotropica 11: 155-158. 
